\title{
OPTIMALE GRONDGEBRUIK AS DOELSTELLING IN DIE LANDBOU
}

\section{Algemeen}

Veel is in die afgelope tyd gesê oor die beskerming van ons natuurlike hulpbronne. Die term natuurlike hulpbronne het uiteraard verskillende betekenisse vir verskillende persone. 'n Natuurlike hulpbron is enige kwaliteit of kenmerk van die natuur wat die mens ekonomies kan gebruik om aan sy behoeftes te voldoen.

Die kenmerke en kwaliteite van natuurlike entiteite is sonder perke - grond, water, plantegroei, minerale, diere en baie meer - die variasie binne elk is ewe groot. Daar was van tyd tot tyd baie belangstelling in inventarisse oor hulpbronne; maar enige inventaris van hulpbronne is nutteloos indien dit nie gekoppel is aan 'n spesifieke ekonomiese gebruik, m.b.v. bekende tegnologie nie.

Die rol wat tegnologiese ontwikkeling gespeel het om die kenmerke en kwaliteite van hulpbronne vir menslike benutting effektief aan te wend is welbekend. Uraan wat vir 'n lang periode slegs 'n element was wat die nuuskierigheid geprikkel het, het oornag internasionale strategiese status verkry. Later het ontdekkings van nuwe afsettings, tot daardie stadium onbekend, ' $n$ oorstroming van die mark tot gevolg gehad. Uraan het dus verval na die posisie van 'n potensiële hulpbron.

Die doel wat nagestreef word in die gebruik van hulpbronne is ewe belangrik. Die verkryging van die grootste moontlike inkomste, gemeet in netto wins, is gewoonlik die belangrikste doelwit. Natuurlike hulpbronne is uiters uiteenlopend en variërend. Sommige hulpbronne is sogenaamd "vloeiend" met 'n groot verskeidenheid gebruike sonder dat die hulpbron as sulks in waarde verminder of verlore gaan: Die kenmerke van uitputbare maar aanvulbare hulpbronne is natuurlike plantegroei en grondvrugbaarheid. Beide kan gebruik en hernu word - in elk geval tot ' $n$ redelike mate. Grondvrugbaarheid kan aangevul word wanneer plantvoedingsmateriaal opgebruik is, selfs al is daar ' $n$ geringe mate van grondverlies. Indien grondverlies per jaar egter toegelaat word om groter te wees as grondvorming gedurende dieselfde periode dan het ons te make met 'n uitputbare of nie-hernubare hulpbron. 
Gronde, wat vir die oogmerke van hierdie skrywe die oorweging geniet, is 'n komplekse fisiese kombinasie van hulpbronne. Grond kan erodeer tot kaal rots wat nie binne 'n menseleeftyd kan herstel nie, in welke geval dit 'n nie-hernubare hulpbron word.

Gronde is komplekse mengsels van fisiese en biologiese materiaal wat 'n aantal funksies in landbou en ander menslike aktiwiteite vervul. Die morfologie van ongeskonde gronde reflekteer die invloed van vyf basiese grondvormende faktore: moedermateriaal, klimaat, biologiese aktiwiteit, reliëf en tyd. Elkeen van die faktore affekteer en modifieer die effek van die ander op die morfologie van die grond asook die eienskappe en kwaliteit. Met die groot hoeveelheid variante is dit dus duidelik dat daar 'n groot aantal teoretiese (en matematiese) kombinasies moontlik is. In die praktyk kom sommige van die kombinasies egter nie voor nie. Nietemin het grondkundiges 'n groot aantal verskillende grondtipes onderskei. Die verskillende tipes word nie van mekaar geskei deur skerp grense nie maar deur oorgangssones. Die verskille tussen verskillende grondtipes is van kardinale belang.

Bodemopnames behels die vasstelling van grense en die rangskikking van gronde in verskillende klasse. So 'n rangskikking word taksonomie genoem (Gr. nemein, om te rangskik; taxis, verskillende klasse). Onderafdelings word op kaarte geskei deur grense. Grense is baie belangrik omdat kwaliteit verander by grense. Dit is waarom die verskille tussen gronde van fundamentele belang is nie alleen vir die landbou nie maar ook vir baie ander vertakkinge van die menslike aktiwiteit.

Grond vervul veelvuldige funksies. Dit is die fisiese medium waarin plante groei. Die grond hou vog, waaruit plante hul voorraad vog verkry. In der waarheid bestaan 'n grond uit miljoene mikroskopiese opgaardamme waarin water beweeg wanneer dit reën of besproei word; waaruit die plante die vog wat dit nodig het trek. Hierdie stoorplek vir water in grond is baie belangrik en varieer van grondtipe tot grondtipe en selfs binne grondtipes. Dit het 'n groot invloed op die kwaliteit van 'n grond vir benutting deur plante.

Grond is die bron en stoorplek vir voedingsmateriaal van natuurlike plante of van akkerbougewasse. Die natuurlike vrugbaarheid van gronde varieer van uiters vrugbaar tot feitlike steriliteit. Grondvrugbaarheid kan geamendeer word deur die 
toediening van kommersieel vervaardigde bemestingstowwe wanneer dit van nature nie in staat is om aan die hoër vereiste van produksie te voldoen nie. Verskillende grondtipes verskil egter radikaal in hul behoefte aan toegediende bemestingstowwe en hul kapasiteit om dit effektief aan plante te voorsien. Die bygevoegde materiaal kan chemies gebind word deur materiaal wat alreeds in die grond is en daarom te stadig aan plante voorsien word of dit mag glad nie toeganklik wees nie. In ander gevalle mag dit te vinnig uitgewas word of die grond het dit glad nie nodig nie. Hierdie aspekte verander op die grense tussen gronde.

Grond is die tuiste van mikrobiologiese flora en fauna, wat op hul beurt weer ' $n$ belangrike rol speel in die vrystelling van chemiese bestanddele van die moedermateriaal asook ander chemiese transformasies. Die produksie van verskillende tipes humus is nou verwant aan die mikrobiologiese aktiwiteit soos gekondisieer deur basisversadiging en die teenwoordigheid van twee-waardige katione op die uitruilingskompleks. In wese kan grond beskou word as 'n chemiese laboratorium waarin verskillende chemiese prosesse met verskillende gevolge plaasvind. Die doeltreffendheid en aard van die prosse varieer by grond. grense.

Gronde kan heeltemal degradeer uit die oogpunt van die ekonomiese gebruik daarvan. Die bestanddele van grond kan fisies van hul oorspronklike posisie verwyder word deur water, wind of deur die mens met masjinerie. Die mens kan die volume of spoed van water wat oor die oppervlak vloei verander deur sy bewerkingsmetodes of hy kan die plantbedekking wat die grond teen die effekte van water en wind beskerm verander. Die erns van die gevaar van verlies aan bogrond hang tot 'n groot mate af van wat onder die bogrond voorkom. Indien die bogrond onderle word deur soortgelyke materiaal dan is die verlies, alhoewel ernstig in 'n sekere sin, nie sodanig dat dit nie die moontlike ontwikkeling van 'n nuwe bolaag verhoed nie. Indien die bogrond dun is en onderle word deur rots, gruis of digte klei, beteken dit dat nuwe grond slegs oor 'n lang tyd kan vorm - lank in 'n geologiese sin maar nooit uit die oog. punt van persone wat op die huidige oomblik die grond gebruik nie. So 'n grond is dus permanent beskadig. Dieselfde besteding sal dus nie dieselfde opbrengs lewer as in die verlede nie. Of in die sin soos wat ons ' $n$ natuurlike hulpbron aan die begin 
gedefinieer het - die kwaliteit van die hulpbron is permanent beskadig. Die hulpbron is dus verbruik.

Gronde kan tydelik uitgeput raak aan plantvoeding maar die proses is omkeerbaar. Van al die faktore wat produksie bepaal is grondvrugbaarheid die maklikste kontrolleerbaar, mits die behoefte van die grond bekend is sowel as die voedingsbehoefte van die spesifieke plante. Verbrakkingsprobleme mag deur onoordeelkundige besproeiing veroorsaak word. Die gronde word daardeur onproduktief. Solank die produksiekapasiteit net nie permanent beskadig is nie kan die kwaliteit herstel word. Wat egter belangrik is, is dat die kwesbaarheid teen water en winderosie asook die snelheid waarmee verbrakking plaasvind varieer van grondtipe tot grondtipe. Hierdeur word die metode van bekamping van bogenoemde gevare geaffekteer.

Wanneer die mens grond gebruik, verander hy dit gewoonlik drasties. Die basiese belangstelling van die landbouer in enige grond is dus nie waarom dit op 'n sekere plek voorkom en wat sy kenmerke is nie, maar hoe dit sal reageer onder bestuur vir verskillende doeleindes waarvoor dit gebruik word. Ons weet dat verskillende grondtipes verskillend sal reageer, maar watter behandeling nodig is vir die optimale reaksie is nie bekend nie. Hoofsaaklik as gevolg van die feit dat feitlik alle waarnemings of proefwerk wat tot dusver in Suid-Afrika gedoen is, van watter aard ook al, op ongedifferensieerde grondtipes gedoen is.

Ondervinding is die basis waarop uitsprake gemaak moet word. Ondervinding of proefondervinding het relatief min waarde indien dit nie betrekking het op gedifferensieerde entiteite waarvan die omvang en geografiese posisie bekend is nie. Dit is om hierdie rede dat gronde geklassifiseer moet word. Klassifikasie berus op differensiasie volgens kenmerke. Bitter weinig indien enige van die landboukundiges in S.A. of elders kan die kenmerke van gronde interpreteer in terme van eienskappe en kwaliteit. Die bepaling van die kwaliteit van grond ten opsigte van erosiekwesbaarbeid en benutting vir enige doeleinde en die daarstelling van optimale benuttingspraktyke behoort die belangrikste onderwerp van landbounavorsing en voorligting te wees. Slegs deur gebruik te maak van gedifferensieerde grondtipes kan die beperkings en moontlikhede deur wetenskaplike navorsing geīnterpreteer word. Grond- 
kaarte en rapporte is van relatief min waarde as die eenhede daarop gedelinieer nie gebruik word nie. Die landbouer se plaas is geleë op 'n segment van die landskap waarin gewoonlik meer as een grondtipe voorkom, en binne die spesifieke grondtipe is daar nog variasies in helling, diepte tot ondeurdringbare lae, klipperigheid ens. Die persoon wat die interpretasie van die geklassifiseerde gronde in terme van kwaliteit moet aanwend as ' $n$ hulpmiddel tot die daarstelling van 'n gewenste lewenstandaard, kan die bruikbaarheid van 'n grondklassifikasie betwis indien dit vir een spesifieke grondtipe gemaak is sonder inagneming van variasies binne die grondtipe en konsiderasie vir ander geassosieerde grondtipe wat ook op sy plaas voorkom.

\section{Grondkaarte}

Op 'n grondkaart word elke grondtipe 'n naam gegee. Namate ons kennis van so ' $n$ spesifieke grond toeneem dra die naam meer en meer inligting in terme van kwaliteit vir die gebruiker.

Omdat baie gebruikers van grondkaarte en rapporte nie bekend is met gronde, kaarte in die algemeen en die beperkings en voordele van kennis oor gronde nie, is dit nodig dat spesiale pogings aangewend word om die kennis by te bring by beide beamptes en boere, asook by persone wat gemoeid is met beleid.

Die eerste les hierin sal wees om die persone wat met landboukundige en regionale beplanning gemoeid is te onderrig in die verskillende tipes en funksies van grondkaarte:

(1) Vir regionale beplanning word veralgemeende grondkaarte vereis om gebiede vir alternatiewe gebruike aan te dui.

(2) 'n Semi-gedetailleerde kaart word benodig om spesifieke geblede vir spesifieke gebruike en behandeling af te sonder.

(3) 'n Gedetailleerde grondkaart word vereis van individuele plase waarop boere oor die variasies, wat van belang is vir hul bestuur, binne elke grondtipe (diepte, hellings, tekstuur) ingelig kan word.

Wanneer 'n grondkaart vir gebruik deur die landbou voorberei word, is die bodemkundige beperk tot ' $n$ redelike skaal. Die gebruik van kaarte met 'n skaal van $1: 1$ is onmoontlik. Hier word ' $n$ onderskeid gemaak tussen grondkaarte met 'n 
skaal van 1:50000 vir algemene gebruik en regionale beplanning. Grondkaarte vir gebruik op individuele plase het 'n skaal van 1:6000 vir akkerbougebiede en 1:10000 vir ekstensiewe weidingsgebiede. As gevolg van die geleidelike oorgange van grondgrense kan die grense van individuele gronde nie akkuraat ingetrek word nie. Hoe groter die skaal hoe akkurater is die grens. Baie grootskaal-kaarte is egter feitlik waardeloos vir algemene beplanning, want hier is die vereiste 'n oorsig oor die gronde van 'n streek. Dus moet dit altyd in ag geneem word dat die gronde of grondtipe wat saam gegroepeer is in 'n karteringseenheid byna nooit $100 \%$ suiwer is nie, m.a.w. klein persentasies kom as onsuiwerhede daarin voor.

\section{Nut van grondkaarte vir die individuele boer}

Oor die algemeen is die stelling waar dat tot die huidige die keuse van grondgebruik hoofsaaklik aan die ondernemingsgees van die boer oorgelaat is. Die boere het meesal hulle gewasse gekonsentreer in streke waar gronde die meeste geskik is daarvoor. Op individuele plase en in die oorgangsgebiede is hierdie stelling egter nie juis nie. Hier is baie misgetas, aangesien diversifikasie van grondgebruik, dit is die gebruik van elke grond volgens sy potensiaal en behandeling volgens sy behoeftes, gestrem is deur regionale boerdery-patrone. Op die meeste plase kom verskillende grondtipes voor, en binne grondtipes is daar variasies in potensiaal. Elk moet verskillend behandel en bestuur word. Wat veral ontstellend is is dat die pryse wat die afgelope tye betaal is op streekspatrone gegrond is of gebaseer is op die aantal morg geploegde land, sonder inagneming van grondverskille of verskille in grondpotensiaal. 'n Ander faktor wat kommer wek is dat die prys van landbougrond en ook waardasie daarvan nie uitsluitlik deur die intrinsieke landbouwaarde bepaal word nie maar deur pryse wat betaal is vir dorpsontwikkeling en deur owerhede om grond vir ander doeleindes te bekom.

In baie gevalle het boere onoordeelkundige beleggings in geboue en gereedskap gemaak op grond met 'n lae potensiaal of te veel betaal vir sulke gronde. Ekonomiese faktore vereis dan dat die rente of kapitaal uit die plaas self verhaal word. In meeste gevalle gebeur die teenoorgestelde.

Die grootste probleem bly egter nog die menslike faktor. Boere het nie geweet, en baie weet vandag nog nie dat beter 
gronde elders bestaan wat teen dieselfde of selfs laer kostes bekom kan word nie. Persone wat gronde waardeer en/of krediet verskaf het geen konsep van landbouwaardes van individuele plase nie.

Dit is die skrywer se oorwoë mening dat landbou-ontwikkeling in Suid-Afrika slegs tot sy reg kan kom as boere in staat gestel word om hul gronde te gebruik volgens hul potensiaal en te behandel volgens hul behoeftes.

\section{Opvoedingsprogramme is noodsaaklik}

Die skeiding van gronde in karteringseenhede is gebaseer op grondkenmerke asook die opeenvolging van horisonne, die kleur, tekstuur, ens. Hierdie kenmerke kan nie direk geinterpreteer word in terme van eienskappe of kwaliteit nie tensy daar gekontroleerde korrelasies oor hierdie aspekte op individuele grondtipes gedoen word. Om hierdie rede is dit gebiedend noodsaaklik dat verdere navorsing of waarnemings uitgevoer word op die gedifferensieerde eenhede wat betref sulke aspekte soos vrugbaarheid, gewaskeuse, grondwaterverhouding en erosiekwesbaarheid. Om die navorsing oor groot gebiede van toepassing te maak, m.a.w. om aan die resultate voorspellingswaarde of toepassingswaarde toe te ken, is dit noodsaaklik dat daar 'n inventaris van gronde en hul lokaliteite in die landskap, m.a.w. grondkaarte moet wees.

'n Grondkaart sonder die gepaardgaande poging om die gegewens tuis te bring by boere, voorligtingsbeamptes, navorsers van alle vertakkinge van die landbou, is alleen van akademiese waarde. Daar moet onthou word dat alle landboukundige aktiwiteite via die plant gaan. Dus is 'n studie van die verhouding plant-grond onder verskillende klimaatstoestande noodsaaklik alvorens 'n grondkaart tot sy reg kom.

Die verskillende moontlike gebruikers van grondkaarte is nie bekend met gronde, terminologie of hoe sekere kenmerke sekere eienskappe en kwaliteite kan beInvloed nie. Onderrigprogramme is daarom nodig om die wenslike gebruik van gronde te propageer. So 'n program is 'n uitdaging, omdat die verskillende persone en instansies wat van grondkaarte moet gebruik maak verskil wat betref hul agtergrond, doelstellinge ens. Om die program suksesvol te loods moet daar op persoonlike vlak deur die grondkundiges deur die hulp van voorligtings- 
programme met die boere kontak gemaak word. Daarom is dit noodsaaklik dat grondkundiges vir lang periodes in bepaalde gebiede moet bly, waar hul deel vorm van 'n ontwikkelingspan met 'n agronoom, agrostoloog en ekonoom om met die voorligtingsbeampte die gebied te ontwikkel.

Ten slotte kan daarop gewys word dat insig met betrekking tot die kwaliteit en bestuur van hulpbronne die gevolg is van gesonde oordeel, ondervinding en 'n gebalanseerde siening, wat nooit verkry sal word as administratiewe en ander motiewe die doel en funksie van die strewe na beter landboupraktyke oorheers nie.

Die skepping van biologiese materie is nie 'n proses van samevoeging van steriele bestanddele onder menslike bestuur nie. Dit is die gevolg van die natuur self se unieke integrasie van biochemiese prosesse oor lang periodes. Die mens se posisie is slegs die van 'n geseënde koördinator met die natuurlike wette-basis, of op sy slegste wanneer dit geïgnoreer word 'n vernielsugtige korttermyn-materialis.

Daar kan geen sprake wees van dogmatiese sienswyses, standaard-oplossings of geykte metodes alvorens alle aspekte deeglik ondersoek is nie. Hierdie aspekte kan alleen behoorlik in ag geneem word as daar ' $n$ volwasse siening oor die aangeleentheid aanwesig is by almal wat daarby betrokke is. Slegs dan kan ons tot 'n gebalanseerde bestuur van hulpbronne kom wat in harmonie is met die natuur self.

P.U. vir C.H.O.

H. J. von M. Harmse. 